\title{
Article \\ Changing Fertilizer Management Practices in Sugarcane Production: Cane Grower Survey Insights
}

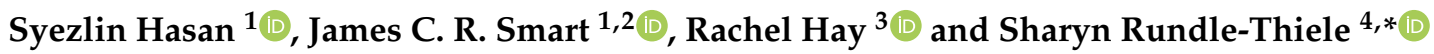 \\ 1 Australian Rivers Institute, Griffith University, Brisbane, Queensland 4111, Australia; \\ s.hasan@griffith.edu.au (S.H.); j.smart@griffith.edu.au (J.C.R.S.) \\ 2 School of Environment and Science, Griffith University, Brisbane, Queensland 4111, Australia \\ 3 College of Business, Law and Governance, James Cook University, Townsville, Queensland 4811, Australia; \\ rachel.hay@jcu.edu.au \\ 4 Sharyn Rundle-Thiele, Social Marketing @ Griffith, Griffith University, Brisbane, Queensland 4111, Australia \\ * Correspondence: s.rundle-thiele@griffith.edu.au; Tel.: +61-7-3735-6446
}

\section{check for}

updates

Citation: Hasan, S.; Smart, J.C.R.; Hay, R.; Rundle-Thiele, S. Changing Fertilizer Management Practices in Sugarcane Production: Cane Grower Survey Insights. Land 2021, 10, 98. https://doi.org/10.3390/ land10020098

Received: 7 December 2020

Accepted: 18 January 2021

Published: 22 January 2021

Publisher's Note: MDPI stays neutral with regard to jurisdictional claims in published maps and institutional affiliations.

Copyright: (c) 2021 by the authors. Licensee MDPI, Basel, Switzerland. This article is an open access article distributed under the terms and conditions of the Creative Commons Attribution (CC BY) license (https:// creativecommons.org/licenses/by/ $4.0 /)$.

\begin{abstract}
Improved fertilizer management practice in sugarcane production is a key component in plans to improve Great Barrier Reef (GBR) water quality. Research focused on understanding the wider systemic factors that drive behavioral change in agriculture is currently limited, with the dominant focus on individual farmer and psycho-social factors. Adopting a wider systems perspective, this study examines farming behavior change and the role of supporting services among 238 sugarcane growers (74,597 hectares) in Queensland's Wet Tropics region who completed surveys reporting on changes in the method they used to calculate fertilizer application rates, along with information on their farm business, socio-demographics, and self-reported importance ratings on a variety of topics. Informed by the Theory of Planned Behavior, survey data are analyzed using regression models to identify factors influencing the change from traditional to improved practice, and early adoption of improved practice. Results indicate growers were less likely to change fertilizer practice if they regarded maintaining good relationships with other local growers as being extremely important, had off-farm income, or had not attended a government-funded fertilizer management workshop in the five years preceding the survey. Similar drivers acted to promote or delay early adoption of improved practice. Results demonstrate the influence of government-funded services to support practice change.
\end{abstract}

Keywords: behavior change; fertilizer application; theory; systems science; sugarcane; social norms; extension services; agronomy; management practices

\section{Introduction}

The Great Barrier Reef (GBR) World Heritage Area off the northeastern coast of Queensland, Australia, is a global ecological and cultural icon that has been estimated to contribute more than AUD \$6 billion annually to Australia's national economy [1]. The 2017 Scientific Consensus Statement concluded that, along with the existential threat posed by climate change, poor water quality is a major factor contributing to the declining condition of the GBR's coastal and reef ecosystems [2]. Discharges of nutrients, fine sediments, and pesticides have been identified as the greatest water quality-related risks to the Reef [2], leading to substantial target reductions in end-of-catchment nutrient and fine sediment loads along the GBR coastline [3]. Challenging nutrient load reductions (50-70\% from modelled 2012-12 levels) have been set for the Wet Tropics region, where sugarcane is the major agricultural crop [3].

Improved fertilizer management practice in cane production is a key component in plans to achieve these ambitious targets [4]. The "Six Easy Steps" (6ES) approach for calculating fertilizer application rates to sugarcane has been promoted as the industrypreferred management practice for the past 10 years [5,6]. 6ES uses a region-specific District 
Yield Potential ${ }^{1}$ (DYP) as the starting point for calculating nitrogen application rates for the initial "plant cane" crop and for "ratoon" crops in subsequent (typically four more) years that re-grow as shoots from the original cane stool after harvest [6-8]. Under 6ES, location-specific adjustments are made to the DYP-derived nitrogen application rate to allow for nitrogen mineralization in the soil (determined via soil testing for soil organic carbon), nitrogen fixation via a legume crop grown in the six-month break between the final ratoon in the cropping cycle and planting of a new cane stool, and additional nitrogen inputs via application of sugar mill byproducts [4,9].

6ES nitrogen application rates are lower than grower-developed practices and lower than traditional pre-2000 recommendations [10]. Many cane growers developed their own nitrogen application rates [11,12], as a legacy of the push to increase yield in the industry during the 1980s and 1990s. Kingston and Linedale [13] and Wood et al. [14] reported that "grower-developed" nitrogen application rates were typically higher than the "traditional recommendations" for fertilizer application rates advocated by the Bureau of Sugar Experiment Stations Limited at that time [15].

For the Wet Tropics region, 6ES annual nitrogen application rates at $0.8-1.2 \%$ soil organic carbon content are $120 \mathrm{kgN} /$ ha for plant cane (after a grass/bare fallow) and $140 \mathrm{kgN} / \mathrm{ha}$ for ratoon crops, compared with traditional recommendations for annual application rates of $120 \mathrm{kgN} / \mathrm{ha}$ for plant cane (after a grass/bare fallow) and $160 \mathrm{kgN} / \mathrm{ha}$ for ratoons, and grower-developed practice of $150 \mathrm{kgN} / \mathrm{ha}$ for plant cane and $180 \mathrm{kgN} / \mathrm{ha}$ for ratoons (after a grass/bare fallow) [6] (Table 2 p. 4, Table 5 p. 7). In this representative example, $6 \mathrm{ES}$ nitrogen applications are $22 \%$ lower than indicative grower-developed practices. Studies by Schroeder et al. [16] and Calcino et al. [5] (both cited in [17]) showed that $82 \%$ and $44 \%$ of growers applied nitrogen at rates in excess of the traditional recommendations to plant cane (after a bare fallow) and ratoon cane, respectively. This is thought to be primarily because of their conservative approach to managing cropping risk [18]. Drawing on their earlier work [19], Schroeder et al. [17] note that these application behaviors gave rise to a number of "symptoms of inefficiency" including: infrequent use of soil and leaf testing, over application of nitrogen and phosphorus, and a general belief that "more fertilizer was better than less" [17] (p. 22).

With regard to cane yield, field evaluations (participative replicated demonstration strip trials) conducted over two successive ratoon crops indicated that 6ES nitrogen applications produced comparable yields to those obtained from traditional recommendations and grower-developed practice [20]. With regard to profitability, partial net returns calculated from field evaluations [20] indicated that 6ES fertilizer application rates should benefit cane growers and sugar millers. ${ }^{2}$ Losses to the environment are strongly affected by the nitrogen surplus that is not taken up by the crop [21]. Consequently, nutrient losses to the GBR are predicted to be lower under 6ES compared with traditional recommendations-and particularly when compared with grower-developed fertilizer management practice [22].

However, despite demonstrating the performance of $6 \mathrm{ES}$ and trialing a range of different approaches to promote its uptake (e.g., agricultural extension advice, industry-led certification programs, federally funded grants for equipment upgrades, and marketbased incentives $[23,24]$ ), it has proved extremely difficult to persuade cane growers to further reduce fertilizer application rates from grower-developed practice or traditional recommendations [25].

Research under the Federal Government-funded National Environmental Science Program's Tropical Water Quality Hub (NESP TWQ) (https:/ / nesptropical.edu.au) has begun to address this issue by harnessing behavior change approaches to investigate potential reasons for growers' unwillingness to change their fertilizer application rates [26,27].

1 District Yield Potential (DYP) is calculated as the estimated highest average annual cane yield (tonnes/ha) for the region concerned, multiplied by a factor of 1.2 [7]. DYP for the Wet Tropics region is 120 tonnes/ha [6].

2 Partial net returns reported in [20] were calculated based on a sugar price of AUD \$320/tonne sugar and a fertilizer price of AUD 1.56/ $\mathrm{kgN}$, as pertained in June 2009. 
In NESP TWQ-funded research, Hay et al. [26] applied structural equation modelling (after [28]) to attitudinal and behavioral data collected in a survey completed by cane growers [29]. This research identified that individual attitudes and perceived subjective norms help shape growers' fertilizer application choices, in line with Ajzen's Theory of Reasoned Action [30,31]. Their work supports previous studies such as Zeweld et al. [32] who applied the Theory of Planned Behavior (hereafter referred to as TPB), which is an extension of the Theory of Reasoned Action, as a theoretical framework to analyze intentions to change growing practices. The Zeweld et al. [32] study identified that attitudes and normative issues positively explain farmers' intentions to adopt new growing practices and perceived behavioral control influences intention to apply minimum tillage.

Psycho-social theories such as the TPB suggest that changing the way a farmer thinks (attitudes), their understanding of what other farmers do (social norms), or their ability to perform the recommended behavior (behavioral control) can increase intentions to perform the behavior and this, in turn, leads to changes in farming practices. However, farming practice change is situated within complex settings. Systems thinking is a conceptual and methodological approach that seeks to address problems within the very complexity that produces them [33]. It is argued that by modelling the many and varying stakeholders, stakeholder interactions, and including the sociocultural beliefs and values operating in a system, it is possible to design more effective behavior change initiatives, given individual, structural and social relationships are taken into account [34,35]. Application of a systems thinking approach acknowledges that behaviors must be addressed within the very complexity that produces them; therefore, examining the importance of factors such as servicing debt, farm decision making responsibilities, farm size, participation in workshops delivered by extension service and agronomy service providers, grants received, and receipt of off-farm income can extend understanding of the factors influencing behavior change in order to learn more about how and why practice change occurs. By exploring elements of complexity, including assumptions, sociocultural beliefs, values, operations, and interactions within a system, it is possible to identify factors facilitating and preventing changes in farming practices and water quality improvements to benefit the Great Barrier Reef (GBR).

Drawing on data from the first round of the Farr et al. survey [29], this study uses logistic and count data regressions to explore whether concepts from the TPB and wider systems factors can help explain behavior change (logistic regression model) and (selfreported) early adoption of lowered fertilizer application behaviors (count data regression model). Reduced fertilizer applications benefit local waterways and the GBR through decreased nutrient loads from sugarcane production in Queensland's Wet Tropics.

\section{Materials and Methods}

This paper utilizes secondary data from [29] collected via a face-to-face survey conducted with 248 sugarcane growers in the Wet Tropics. Two hundred and thirty-eight respondents who completed the survey stated that the major land use on their main property was sugarcane production and provided the approximate area used for sugarcane cultivation. Across those 238 respondents, the total land area used for sugarcane was 74,597 hectares. The survey provided data on attitudes, social norms, and perceived behavioral control from a TPB perspective, together with the characteristics of growers' farm businesses, participation in a range of practice change initiatives, and other individual and sociodemographic characteristics. The survey ascertained the method growers used to calculate the amount of fertilizer they applied on land they owned/managed, and whether they had always used their current method (and if not, how long ago they switched to their current method).

The survey also obtained data on the importance growers assigned to key issues when making decisions about what to do on their land. These importance responses were recorded on a seven-point unipolar semantic scale, where a " 1 " is "Extremely unimportant or irrelevant", a " 4 " is "Neutral", and "7" is "Extremely important or essential". 
Responses regarding the importance growers assigned to three of the issues when making farming decisions-minimizing sediment runoff and/or nutrient losses; safeguarding local waterways; safeguarding the GBR — can be collectively regarded as a TPB measure of environmental attitude (Cronbach's $\alpha=0.86$ ). The importance assigned to maintaining family traditions and heritage, maintaining good relations with other local growers, and having efforts recognized by the wider community could be regarded as TPB subjective norms; however, Cronbach's $\alpha$ was insufficient to justify combining these three measures into a single indicator $(\alpha=0.49)$, so each item was retained separately. Assigning high importance to servicing debt could be regarded as a TPB perceived behavioral control on intention (particularly as some forms of low-nitrogen fertilizer management require purchase of new equipment) [36].

Moving beyond TPB constructs, the following farm characteristics were also recorded: decision-making responsibilities, farm size, and whether or not the farming business obtained income from off-farm activities. Additionally, years of cane growing experience and a self-stated life satisfaction score were recorded as grower characteristics, together with standard sociodemographics. Level of life satisfaction was stated on a scoring scale from 0 to 100, with 100 representing very satisfied, 0 very unsatisfied, and 50 neutral. To explore the potential influence of government-funded grants and workshops on change of fertilizer practice, respondents stated how many workshops they had attended (none, five or less, more than five), and how many grants they had applied for (none, three or less, more than three) in the five years preceding the survey. Survey respondents were asked if they were solely responsible for decision making on their property, or whether decision making responsibility was shared with others (spouse, parents, children, brother, in-laws, or others).

A logistic regression model was used to initially identify TPB factors that exerted statistically significant influences on the probability that growers had changed fertilizer practice (i.e., fertilizer application rate) on land they owned/managed. Subsequently, the same logistic regression model was expanded to also include characteristics of the farm business, sociodemographics of the respondents, workshop attendance, and grants applied for as additional drivers of fertilizer practice change. The general statement of the logistic regression model is

$$
F_{i}=f\left(\boldsymbol{T P B}_{i}, \boldsymbol{F B C}_{i}, \boldsymbol{S O C}_{i}, W_{i}, G_{i}\right)+e_{i}
$$

where $F_{i}$ is the (binary) response to whether respondent $i$ had changed their fertilizer calculation method (i.e., fert_practice_change). $\mathbf{T P B} \boldsymbol{B}_{i}$ is a vector of $\mathbf{T P B}$ constructs pertaining to grower $i$ 's environmental attitudes (environmental_attitude), social norms (family_traditions, relationships_local_growers, efforts_recognized), and perceived behavioral controls (debt_servicing, shared_decision) as described previously. $F B C_{i}$ and $S O C_{i}$ are vectors of respondent $i$ 's farm business characteristics (farm_size, off_farm_income) and sociodemographics (age, male, cane_growing_experience, life_satisfaction), respectively. $W_{i}$ and $G_{i}$ represent the number of workshops attended and grants applied for, respectively, in the five years prior to completing the survey. $e_{i}$ is the error term, which is assumed to follow a binomial distribution.

For those growers who had changed their fertilizer application rate, the number of years since they made that change is also of interest. Specifically, these data can be used to identify factors that influence the early adoption of lower water quality risk fertilizer application behaviors among cane growers in the Wet Tropics. The objective here is to analyze, in a regression context, the number of years since switching (i.e., years_switched), in response, initially, to a set of TPB constructs only as drivers, and, subsequently, to TPB constructs, with farm business characteristics, and grower sociodemographics as additional drivers. The most commonly used count data models in applied studies are the Poisson and negative binomial regression models [37]. A Poisson regression model assumes equality of the conditional mean and variance (i.e., equidispersion) of the count variable years_switched. If this assumption does not hold (i.e., data exhibit overdispersion whereby the conditional variance exceeds the conditional mean), a negative binomial regression model is more 
appropriate $[37,38]$. The negative binomial model for the number of years since grower $i$ switched or changed the basis of their fertilizer practice, $y_{i}$, can be written in log-linear form as:

$$
\ln y_{i}=\sigma+\boldsymbol{\beta} \mathbf{T P B _ { i }}+\gamma \boldsymbol{F} \boldsymbol{B} \boldsymbol{C}_{i}+\boldsymbol{\rho} S \boldsymbol{O O C _ { i }}+\omega W_{i}+g G_{i}+\epsilon_{i}
$$

where the subscript $i$ is an index for respondent; $\sigma$ is a constant term; $\beta, \gamma$, and $\rho$ are vectors containing the coefficients to be estimated for the vectors of drivers TPB, $F B C$, and $S O C$ as defined for Equation (1). The coefficients $\omega$ and $g$ are estimated for the independent variables $W_{i}$ and $G_{i} . \epsilon_{i}$ is the error term, which is assumed to follow a gamma distribution.

\section{Results}

\subsection{Descriptive Statistics}

A total of 238 sugarcane growers completed surveys reporting on changes in fertilizer application and focal factors that may explain behavior change. As shown in Table 1, of the 238 Wet Tropics sugarcane growers surveyed, 89 (37\%) had at some point changed the method they used to calculate fertilizer application rate for the cane land they owned/managed. Those who had changed their basis for this calculation made that change between 1 and 45 years ago (mean number of years since making the change is 8.4 years and standard deviation is 8.1 years). Descriptive statistics of key data are summarized in Table 1.

Table 1. Descriptive statistics of variables included in the logistic and count data regression models. The number of responses for each variable reflects the number of complete answers received.

\begin{tabular}{|c|c|c|c|c|c|}
\hline Variable & Description & Mean & Median & Std. dev. & $\begin{array}{c}\text { No. of } \\
\text { Responses }\end{array}$ \\
\hline \multicolumn{6}{|l|}{ Dependent variables } \\
\hline fert_practice_change & $\begin{array}{l}\text { Binary variable indicating respondent has changed } \\
\text { fertilizer practice }(=1,0 \text { otherwise). }\end{array}$ & 0.37 & 0 & 0.48 & 238 \\
\hline years_since_prac_change & $\begin{array}{c}\text { Number of number of years since growers changed } \\
\text { fertilizer practice. }\end{array}$ & 8.38 & 5.5 & 8.11 & 84 \\
\hline \multicolumn{6}{|c|}{ Independent variables: Theory of planned behavior constructs (TPB) } \\
\hline environmental_attitude ${ }^{1}$ & $\begin{array}{l}\text { Measure of attitude: minimizing runoff and } \\
\text { safeguarding water quality. }\end{array}$ & 6.44 & 6.67 & 0.73 & 235 \\
\hline family_traditions $^{2}$ & $\begin{array}{l}\text { Measure of importance of maintaining family } \\
\text { traditions and heritage. }\end{array}$ & 2.74 & 3 & 0.53 & 236 \\
\hline relationships_local_growers ${ }^{1}$ & $\begin{array}{l}\text { Measure of a social norm: maintaining good } \\
\text { relationships with other local growers. }\end{array}$ & 6.13 & 6 & 0.88 & 236 \\
\hline efforts_recognized ${ }^{2}$ & $\begin{array}{l}\text { Measure of a social norm: having efforts recognized } \\
\text { by the wider community. }\end{array}$ & 2.36 & 3 & 0.78 & 233 \\
\hline debt_servicing ${ }^{2}$ & $\begin{array}{c}\text { Perceived behavioral control on intention: } \\
\text { prioritizing servicing debt. }\end{array}$ & 2.79 & 3 & 0.52 & 229 \\
\hline \multicolumn{6}{|c|}{ Independent variables: Farm business characteristics $(F B C)$} \\
\hline shared_decision & $\begin{array}{c}\text { Perceived behavioral control: in relation to decision } \\
\text { making (own decision }=1 \text {, joint or shared decision } \\
\text { with spouse, parents, children, brother, in-laws, or } \\
\text { others }=2 \text { ). }\end{array}$ & 1.475 & 1 & 0.50 & 236 \\
\hline farm_size & Size of sugarcane area in hectares. & 313 & 112.5 & 596 & 238 \\
\hline off_farm_income & $\begin{array}{c}\text { Binary variable indicating respondent (and/or } \\
\text { spouse) has another source of income }(=1,0 \\
\text { otherwise). }\end{array}$ & 0.57 & 1 & 0.50 & 238 \\
\hline \multicolumn{6}{|c|}{ Independent variables: Sociodemographics $(S O C)$} \\
\hline age & Respondent's age (years). & 56.81 & 57 & 12.02 & 237 \\
\hline male & $\begin{array}{c}\text { Binary variable indicating respondent is male }(=1,0 \\
\text { otherwise). }\end{array}$ & 0.97 & 1 & 0.16 & 234 \\
\hline cane_growing_experience & $\begin{array}{c}\text { Number of years respondent has been managing a } \\
\text { sugarcane farm. }\end{array}$ & 29.34 & 27 & 17.13 & 231 \\
\hline life_satisfaction & $\begin{array}{l}\text { Self-stated level of life satisfaction on a scale } \\
\text { between } 0 \text { (very unsatisfied), } 50 \text { (neutral), and } 100 \\
\text { (very satisfied). }\end{array}$ & 78.52 & 80 & 16.58 & 234 \\
\hline
\end{tabular}


Table 1. Cont.

\begin{tabular}{|c|c|c|c|c|c|}
\hline Variable & Description & Mean & Median & Std. dev. & $\begin{array}{c}\text { No. of } \\
\text { Responses }\end{array}$ \\
\hline \multicolumn{6}{|c|}{ Independent variables: Engagement with workshops and grants ( $W$ and $G$ ) } \\
\hline workshops_attended & $\begin{array}{l}\text { Categorical variable indicating the number of } \\
\text { workshops attended in the preceding five years } \\
\text { (participated in more than } 5=1 \text {, participated in } 5 \text { or } \\
\text { less }=2 \text {, not participated in any }=3 \text { ). }\end{array}$ & 2.0 & 2 & 0.42 & 236 \\
\hline grants_applied & $\begin{array}{c}\text { Categorical variable indicating the number of grants } \\
\text { applied for in the preceding five years (applied for } \\
\text { more than } 3=1 \text {, applied for } 3 \text { or less }=2 \text {, did not } \\
\text { apply for any }=3 \text { ). }\end{array}$ & 2.13 & 2 & 0.55 & 235 \\
\hline
\end{tabular}

${ }^{1}$ On a 7-point scale ranging between 1 (Extremely unimportant/irrelevant), 4 (Neutral), and 7 (Extremely important/essential). ${ }^{2}$ On a 3-point scale ranging between 1 (Unimportant/irrelevant), 2 (Neutral), and 3 (Important/essential).

\subsection{Results of the Logistic Regressions}

Results obtained from fitting a logistic model in linear form to the complete dataset for Model 1 (TBC constructs only) $(n=223)$ and Model $2(n=212)$ (TPB constructs, FBC, $S O C, W$ and $G$ ), with fertilizer practice change as the dependent variable, are shown in Table 2. Across both models, relationships with other local growers as a TPB measure of a social norm is a statistically significant driver of fertilizer practice change. All other things equal, growers who do not regard maintaining good relationships with other local growers as extremely important (the baseline category) are more likely to have changed their fertilizer practice. When only including TPB constructs as drivers (Model 1), growers were more likely to have changed the basis for their fertilizer calculation rate if they were neutral (as opposed to agreeing or disagreeing) regarding the importance of having their efforts recognized by the wider community as an important factor in their farm decision making, all else equal.

When farm business characteristics, grower sociodemographics, and engagement with workshops and grants were added as independent variables, alongside the TPB constructs (Model 2), the TPB construct regarding the importance of maintaining good relationships with other local growers remained significant. Attendance at workshops and having a source of off-farm income were also statistically significant at $10 \%$ or better in Model 2 . All other things equal, growers whose business has a source of off-farm income are less likely to have changed their fertilizer practice, as are growers who had not attended a fertilizer management workshop in the five years preceding the survey.

The fit of the logistic regression results in Table 2 is evaluated by the HosmerLemeshow goodness of fit test [39] and the area under the ROC curve [40]. The HosmerLemeshow goodness of fit assessment compares the sample frequency of the fert_practice _change variable, within a chosen number of subgroups, with the average predicted probability for each subgroup from the fitted model-under the null hypothesis that the two frequencies are equal i.e., the model is correctly specified [39]. Results of Hosmer-Lemeshow's goodness of fit test for Model 1 and Model 2 for four through to nine subgroups suggest that there is no evidence of lack of fit ( $p$-values range from 0.47 (four groups) to 0.90 (eight groups) for Model 1; $p$-values range from 0.48 (four groups) to 0.93 (nine groups) for Model 2). Results based on Model 1 and Model 2 in Table 2 are also evaluated using the area under the ROC (Receiver Operating Characteristics) curve. The areas under the ROC curves for Model 1 and Model 2 are 0.68 and 0.72, respectively, indicating that the predictive ability of Model 2 exceeds the "acceptable discrimination" ROC threshold of 0.7 as determined by [40]. Furthermore, comparing observed data on fert_practice_change against predictions from Model 1 and Model 2, under the assumption of a symmetric threshold [39], shows that the models correctly classified $65.02 \%$ and $66.51 \%$ of outcomes, respectively. 
Table 2. Logistic regression results for Model 1 (only TPB constructs included as independent variables) and Model 2 (all independent variables included). Dependent variable: fert_practice_change.

\begin{tabular}{|c|c|c|c|c|}
\hline \multirow[b]{2}{*}{ Variable } & \multicolumn{2}{|c|}{ Model 1} & \multicolumn{2}{|c|}{ Model $2^{5}$} \\
\hline & Coefficient & SE & Coefficient & SE \\
\hline constant & $-3.977^{*}$ & 2.139 & -2.693 & 2.470 \\
\hline environmental_attitude & 0.249 & 0.265 & 0.304 & 0.323 \\
\hline \multicolumn{5}{|l|}{ family_traditions 1} \\
\hline neutral & 0.740 & 0.872 & 0.644 & 0.970 \\
\hline important & 0.212 & 0.829 & 0.499 & 0.947 \\
\hline \multicolumn{5}{|l|}{ efforts_recognized ${ }^{1}$} \\
\hline neutral & $-0.818^{*}$ & 0.440 & -0.746 & 0.456 \\
\hline important & 0.044 & 0.381 & 0.188 & 0.390 \\
\hline \multicolumn{5}{|l|}{ debt_servicing ${ }^{1}$} \\
\hline neutral & 1.039 & 0.941 & 0.678 & 0.926 \\
\hline important & 1.342 & 0.839 & 0.940 & 0.835 \\
\hline \multicolumn{5}{|l|}{ relationships_local_growers ${ }^{2}$} \\
\hline neutral & $1.784^{* *}$ & 0.906 & $2.469 * *$ & 1.121 \\
\hline important & $0.921^{* *}$ & 0.471 & $1.001 *$ & 0.530 \\
\hline very important & $1.174^{* * *}$ & 0.340 & $1.085^{* * *}$ & 0.366 \\
\hline shared_decision & -0.119 & 0.301 & -0.164 & 0.333 \\
\hline off_farm_income & & & $-0.579 *$ & 0.326 \\
\hline farm_size & & & 0.00032 & 0.00031 \\
\hline life_satisfaction & & & 0.00059 & 0.00911 \\
\hline cane_growing_experience & & & -0.00690 & 0.00961 \\
\hline workshops_attended ${ }^{3}$ & & & & \\
\hline participated in 5 or less & & & -0.326 & 0.555 \\
\hline not participated in any & & & $-1.818 *$ & 1.034 \\
\hline grants_applied ${ }^{4}$ & & & -0771 & 0519 \\
\hline applied for 3 or less & & & -0.771 & 0.519 \\
\hline did not apply any & & & -0.659 & 0.640 \\
\hline Number of observations & \multicolumn{2}{|c|}{223} & \multicolumn{2}{|c|}{212} \\
\hline Area under ROC curve & \multicolumn{2}{|c|}{0.680} & \multicolumn{2}{|c|}{0.721} \\
\hline McFadden's $\mathrm{R}^{2}$ & \multicolumn{2}{|c|}{0.077} & \multicolumn{2}{|c|}{0.121} \\
\hline Count $\mathrm{R}^{2}$ & \multicolumn{2}{|c|}{0.650} & \multicolumn{2}{|c|}{0.665} \\
\hline
\end{tabular}

Note: Regression with robust standard errors. ${ }^{* * *},{ }^{* *},{ }^{*}$ are significant at the $1 \%, 5 \%$, and $10 \%$ levels, respectively. ${ }^{1}$ Baseline category is not important. ${ }^{2}$ Baseline category is extremely important. ${ }^{3}$ Baseline category is participated in more than $5 .{ }^{4}$ Baseline category is applied for more than 3. ${ }^{5}$ Sociodemographic variables age and male were excluded from this model because they did not improve model fit. Age is highly correlated with years of experience growing cane and only 6 of the respondents are female.

\subsection{Results of the Negative Binomial Regressions}

The Poisson regression model was first implemented to estimate the mean number of years since grower $i$ changed fertilizer practice, conditional on grower $i$ 's TPB constructs (TPB) farm business characteristics $(F B C)$, sociodemographics (SOC), attendance at workshops and grant applications $(W$ and $G)$. Comparison of the mean number of years since growers changed fertilizer practice (8.38) with the variance (65.77) suggests overdispersion. Following [39], a test of overdispersion on the Poisson regression results for Model 1 rejects $(p=0.006)$ the null hypothesis of equidispersion (i.e.,, rejects $\operatorname{Var}(y \mid \mathbf{T P B})=E(y \mid \mathbf{T P B}))$, indicating the presence of significant overdispersion. Repeating the same overdispersion test on the Poisson regression results for Model 2 produces the same outcome $(p=0.001)$. The negative binomial estimates of the overdispersion parameter, $\alpha$, are 0.378 for Model 1 and 0.218 for Model 2. The likelihood ratio test of $\mathrm{H}_{0}: \alpha=0$ (i.e., no overdispersion) is rejected for both Model 1 and Model 2. Based on the outcomes of these overdispersion tests, a negative binomial specification of years_since_prac_change is used in subsequent analyses.

Table 3 shows the estimation results for negative binomial Model 1 and Model 2. For Model 1 (TPB constructs only), all else equal, regarding it as being unimportant to maintain family traditions and heritage when making decisions about managing the 
farm acts to advance the decision to change fertilizer practice. Conversely, being neutral regarding the importance of servicing debt as a factor in farm decision making acts to delay fertilizer practice change. Model 1 also reveals that two further factors also influence the timing of practice change. Regarding it as being extremely important to maintain good relationships with other local growers acts to advance the decision to change fertilizer practice, whereas agreeing that safeguarding the environment from adverse impacts of fertilizer runoff is an important factor in farm decision making appears to delay the adoption decision. When farm business characteristics, grower sociodemographics, and engagement in workshops and grants are added as drivers (Model 2), the following statistically significant factors persist: being inclined to maintain family traditions and heritage; being neutral regarding the importance of servicing debt; and regarding it as being extremely important (i.e., essential) to maintain good relationships with other local growers. Under Model 2, all else equal, growers with more years of experience and those who attended up to five workshops in the preceding five years were more likely to be early adopters of fertilizer practice change. The positive link between early adoption of practice change and years of experience growing sugarcane may simply reflect the increased length of time more experienced growers have been in the industry. Finally, having multiple decision makers (joint or shared decision with spouse, parents, children, brother, in-laws, or others) in farm management activities acts to delay the decision to change the basis of fertilizer rate calculations.

Table 3. Negative binomial regression results for Model 1 (TPB construct included as independent variables) and Model 2 (all independent variables are included). Dependent variable: years_since_prac_change.

\begin{tabular}{|c|c|c|c|c|}
\hline \multirow[b]{2}{*}{ Variable } & \multicolumn{2}{|c|}{ Model 1} & \multicolumn{2}{|c|}{ Model $2^{5}$} \\
\hline & Coefficient & SE & Coefficient & SE \\
\hline constant & $6.839^{* * *}$ & 1.166 & $5.460 * * *$ & 1.151 \\
\hline $\begin{array}{l}\text { environmental_attitude } \\
\text { family_traditions } 1\end{array}$ & $-0.411^{* *}$ & 0.192 & -0.273 & 0.200 \\
\hline neutral & $-1.126^{* * *}$ & 0.366 & $-1.035^{* * *}$ & 0.258 \\
\hline \multicolumn{5}{|l|}{ efforts_recognized ${ }^{1}$} \\
\hline neutral & -0.254 & 0.265 & -0.170 & 0.217 \\
\hline \multicolumn{5}{|l|}{ debt_servicing 1} \\
\hline neutral & $-0.822 * *$ & 0.411 & $-0.903 *$ & 0.493 \\
\hline \multicolumn{5}{|l|}{ relationships_local_growers ${ }^{2}$} \\
\hline neutral & -0.143 & 0.425 & 0.241 & 0.322 \\
\hline important & $-0.583 *$ & 0.313 & -0.335 & 0.243 \\
\hline very important & $-0.747^{* * *}$ & 0.265 & $-0.445^{* *}$ & 0.209 \\
\hline shared_decision & -0.283 & 0.188 & $-0.301 *$ & 0.167 \\
\hline off_farm_income & & & -0.264 & 0.175 \\
\hline farm_size & & & 0.00006 & 0.00007 \\
\hline life_satisfaction & & & -0.00235 & 0.00557 \\
\hline $\begin{array}{c}\text { cane_growing_experience } \\
\text { workshops_attended }{ }^{3}\end{array}$ & & & $0.0208^{* * *}$ & 0.0049 \\
\hline participated in 5 or less & & & $0.403^{* *}$ & 0.162 \\
\hline $\begin{array}{l}\text { not participated in any } \\
\text { grants_applied }^{4}\end{array}$ & & & 0.491 & 0.394 \\
\hline applied for 3 or less & & & 0.020 & 0.213 \\
\hline did not apply any & & & -0.018 & 0.282 \\
\hline Number of observations & \multicolumn{2}{|c|}{82} & \multicolumn{2}{|c|}{81} \\
\hline Log likelihood & \multicolumn{2}{|c|}{-240.374} & \multicolumn{2}{|c|}{-223.400} \\
\hline AIC & \multicolumn{2}{|c|}{6.277} & \multicolumn{2}{|c|}{6.183} \\
\hline
\end{tabular}

Note: Regression with robust standard errors. ${ }^{* * *},{ }^{* *},{ }^{*}$ are significant at the $1 \%, 5 \%$, and $10 \%$ levels, respectively. ${ }^{1}$ Baseline category is not important. ${ }^{2}$ Baseline category is extremely important. ${ }^{3}$ Baseline category is participated in more than $5 .{ }^{4}$ Baseline category is applied for more than $3 .{ }^{5}$ Sociodemographic variables age and male were excluded from this model because they did not improve model fit. Age is highly correlated with years of experience growing cane and all respondents who have changed their fertilizer practice were male. 
To gain further insight into the role of environmental_attitude in the negative binomial regressions, an auxiliary ordinary least squares regression was run with environmental_attitude as a function of family_tradition, relationships_local_growers, efforts_recognise, debt_servicing, shared_decision, cane_growing_experience, and age. The results of this regression, shown in Table 4 , indicate a statistically significant negative link between years of cane growing experience and environmental attitude $(p$-value $=0.083$ ). All else equal, growers with more experience accord less importance to environmental outcomes in their business decision making. When cane growing experience is omitted from the negative binomial regression (Model 1 in Table 3), environmental attitude acts as its (negative) proxy. However, when years of experience is included (Model 2 in Table 3), it displaces the apparent influence of environmental attitude on early adoption of practice change.

Table 4. Ordinary least squares regression results. Dependent variable: environmental_attitude.

\begin{tabular}{|c|c|c|}
\hline Variable & Coefficient & SE \\
\hline constant & $5.770^{* * *}$ & 0.789 \\
\hline \multicolumn{3}{|l|}{ family_traditions ${ }^{1}$} \\
\hline neutral & 0.226 & 0.259 \\
\hline important & 0.231 & 0.271 \\
\hline \multicolumn{3}{|l|}{ efforts_recognized ${ }^{1}$} \\
\hline neutral & $-0.445^{* *}$ & 0.193 \\
\hline important & -0.139 & 0.146 \\
\hline \multicolumn{3}{|l|}{ debt_servicing ${ }^{1}$} \\
\hline neutral & 0.562 & 0.408 \\
\hline important & $0.802 *$ & 0.425 \\
\hline \multicolumn{3}{|l|}{ relationships_local_growers ${ }^{2}$} \\
\hline neutral & -0.743 & 0.483 \\
\hline important & -0.284 & 0.202 \\
\hline very important & -0.158 & 0.162 \\
\hline shared_decision & 0.025 & 0.139 \\
\hline cane_growing_experience & $-0.008 *$ & 0.004 \\
\hline age & 0.004 & 0.007 \\
\hline Number of observations & \multicolumn{2}{|c|}{85} \\
\hline$R^{2}$ & \multicolumn{2}{|c|}{0.209} \\
\hline Adjusted $\mathrm{R}^{2}$ & \multicolumn{2}{|c|}{0.077} \\
\hline
\end{tabular}

\section{Discussion}

The need to systematically compare and contrast theoretical perspectives to advance understanding has been identified [41]. By understanding which theory offers the greatest predictive capability, researchers can deliver guides for practice while simultaneously building the evidence base to advance knowledge. Within farming management practice change research, a strong reliance on theoretical perspectives that focus attention on individuals is evident. Researchers have applied other psycho-social models (e.g., the Transtheoretical Model of Change [42]) and the Theory of Planned Behavior [32,43]. These studies have focused attention on understanding farmer beliefs, farmers' readiness to change, knowledge, barriers to adoption, farmer goals, benefits of practice change adoption, self-efficacy, perceived usefulness, perceived ease of operation, and normative beliefs. Psycho-social theories have assisted researchers to identify how farmers think.

Previous studies applying Ajzen's Theory of Reasoned Action [30,31] and the subsequent Theory of Planned Behavior (TPB) have identified that individual attitudes and perceived subjective norms can help shape change in growers' management practices. For example, Zeweld et al. [32] applied the Theory of Planned Behavior as the theoretical framework to analyze intentions to change growing practices. The study by Zeweld et al. [32] identified that attitudes and normative issues positively explain farmers' intentions to adopt new growing practices and perceived behavioral control influences intention 
to apply minimum tillage. This finding was corroborated in Hay et al. [26] who applied structural equation modelling to attitudinal and behavioral data, identifying that individual attitudes and perceived subjective norms help shape sugarcane growers' fertilizer application choices. These approaches indicate the important role of social norms. By adopting a dynamic analytical approach that examines why farmers do and do not change, the role of social norms can be further illuminated.

Mapping of the empirical results from this study to the Theory of Planned Behavior, shown in Figure 1a, suggests that subjective norms (less than essential to maintain good relations with other local growers) increase intention to change behavior. Insights from this study indicate that growers' participation in up to five workshops may play a role in reshaping attitudes which then positively contribute to behavioral intentions. These drivers of behavioral change intention, together with off-farm income, influence the probability of behavior change (i.e., switching from traditional fertilizer practice to improved 6ES fertilizer practice). With regard to factors influencing early adoption of improved fertilizer practice (see Figure 1b), subjective norms (very important to maintain good relations with other local growers; not important to maintain family traditions and heritage) and workshop participation have also been found to promote behavioral intentions; however, shared decision making as a perceived behavioral control factor is found to delay the adoption of improved fertilizer practice. Finally, this study found that more cane growing experience is associated with early adoption of improved fertilizer practice (Figure 1b), although-as mentioned earlier-this may simply reflect that the timing of behavior change cannot precede a grower's entry to the industry. In summary, the current study identified that $37 \%$ of farmers reported changing their fertilizer rates and early adopters of practice change were less concerned with what other farmers thought, which demonstrates that social norms may be more relevant to adoption across the wider farmer community but are less of a consideration for early adopters of practice change. Further research will be needed to confirm (or deny) this study finding.

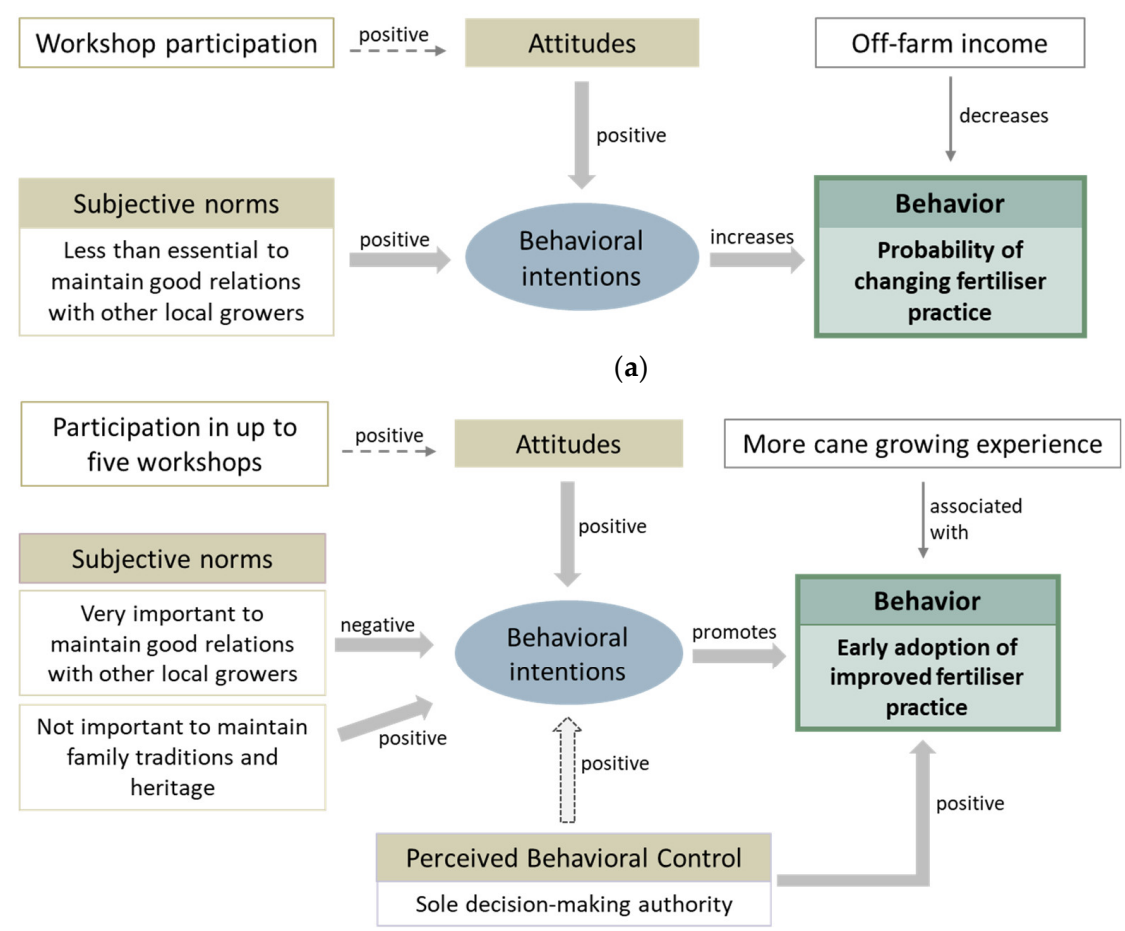

(b)

Figure 1. Mapping of empirical results from this study to the Theory of Planned Behavior. (a) Results from the logistic regression of Model 2: factors influencing the probability of fertilizer practice change; (b) Results from the negative binomial regression of Model 2: factors influencing early adoption of practice change. 
Dominant use of psycho-social theories demonstrates that researchers have come to understand farming practice change as a process where an understanding of the way that farmers think and feel is required to drive behavioral change [44]. While psycho-social theories do serve a purpose (i.e., they provide an understanding of individual-level factors that can be related to explaining current behavior and predicting an individual's behavioral change), investigators cannot "habituate to the perspective afforded by psycho-social theory in the way that one can forget that one is wearing glasses" [44] (p. 150s). The dominant psycho-social theoretical focus restricts understanding, and therefore monitoring and measurement practices, to individuals whose behavior needs to change, and in so doing, ignores the fact that farming practice change occurs in partnerships among stakeholders. Systems standpoints that consider practice change within a constellation of actors, actions, and interactions, or within a complex stakeholder system where mutual value is realized between partners, can extend understanding of how farming practice change can be facilitated and enabled (see [45]).

Examination of the farming practice change evidence base indicates that alternative theoretical viewpoints do exist. For example, the Diffusion of Innovation approach [46,47] captures a range of social factors including access to extension support services, the role of opinion leaders, financial costs, and market forces. Socio-ecological frameworks organize understanding into individual, social, and institutional settings and regulation levels considering additional factors such as network relations. Application of systems frameworks such as Agricultural Innovation Systems (AIS) (see [48]) focuses attention on structural elements (e.g., actors/roles), the functions in an innovation system (e.g., process dynamics), and analyses of how elements and functions interact to identify relative conditions or processes necessary for innovation. In line with wider socio-ecological or systems frameworks, the present study extended research focus beyond individual factors to consider the role partners may play in shaping practice change. The results of this study indicate that farmers who had attended workshops in the last five years were more likely to have changed their fertilizer application rates. This study demonstrates how surveys can be used to extend research focus to capture the role of actors within the practice change system, e.g., the stakeholders who are responsible for delivering workshops including assessments from farmers attending to understand the efficacy of the workshop.

This study is limited to available data within a survey that had previously been applied to examine sugarcane farming practice change in one Australian region. The limitations of this study provide opportunities for future research including extending research focus to other regions and agribusiness sectors using available survey data to examine factors contributing to (or acting against) practice change. Further primary research is recommended to extend understanding of additional systems factors supporting or inhibiting practice change. Factors including experience with support services, satisfaction, and willingness to recommend service providers, and other social and systems factors as indicated in AIS and Diffusion of Innovation approaches should be examined across regions and agri-business contexts to build a Theory of Farming Practice Change, ensuring the actions of stakeholders and interactions between actors are monitored and measured.

\section{Conclusions}

Changing fertilizer application rates is a complex problem. By approaching the problem through a wider systems lens and examining the role that other actors have in shaping farming management practice change (e.g., agronomy and extension service providers who support practice change through one-to-one consultations and groups workshops and governments who provide funding through grant schemes), an understanding of how and why farmers change fertilizer application rate and other farming practices emerges. This study demonstrates how available survey data can be examined to identify rates of farming management practice change and the wider systems factors contributing to reported changes. This study challenges researchers to extend understanding beyond current dominant psycho-social individual-based research enquiries. In this study, social 
norms were an influencing factor and farmers who do not consider it essential to maintain good relationships with other local growers were more likely to report changes in fertilizer application rates. The importance of initiatives supporting practice change (e.g., grants and workshops) was highlighted in this study. Growers who had attended workshops in the last five years reported lowering fertilizer application rates and workshop attendance assisted in promoting earlier adoption of this behavior change. By understanding more about the constellation of actors and actions that occur within the farming context, a wider understanding of factors contributing to farming practice change can emerge.

Author Contributions: J.C.R.S. and S.R.-T. secured funding from the National Environment and Science Program's Tropical Water Quality Hub to support this work. S.H. and J.C.R.S. were responsible for data cleaning, data preparation and data analysis. S.R.-T. led conceptualization and R.H. supplied de-identified data for project team analysis. S.H., J.C.R.S. and S.R.-T. drafted the paper and R.H. provided a critical review and input prior to finalization of the manuscript for peer review. All authors have read and agreed to the submitted version of the manuscript. Authorship is limited to those who have contributed substantially to the work reported. All authors have read and agreed to the published version of the manuscript.

Funding: Data collection was supported with funding from the Australian Government's National Environmental Science Program for Tropical Water Quality Hub Project 2.1.3: Harnessing the science of social marketing and behaviour change for improved water quality in the Great Barrier Reef: an action research project. Conceptualization, data analysis and preparation of this paper were supported with funding from the Australian Government's National Environmental Science Program for Tropical Water Quality Hub Project 4.12: Measuring cost-effectiveness and identifying key barriers and enablers of lasting behavioural change in the cane industry.

Institutional Review Board Statement: The study was conducted according to the guidelines of the Australian Government, Australian Research Council, and approved by the Ethics Committee of JAMES COOK UNIVERSITY Application ID H6455 approved on 3 February 2016.

Informed Consent Statement: Informed consent was obtained from all subjects involved in the study via the Australian Government's National Environmental Science Program for Tropical Water Quality Hub Project 2.1.3: Harnessing the science of social marketing and behavior change for improved water quality in the Great Barrier Reef: an action research project (NESP TWQ Project 2.1.3).

Data Availability Statement: Data were obtained from NESP TWQ Project 2.1.3. The data are not publicly available to protect the privacy of respondents.

Acknowledgments: The research team wish to acknowledge the support of the growers who completed the surveys, the stakeholders who agreed to provide the NESP 4.12 research team with access to data, and all stakeholders who generously gave their time to assist us to understand the project context. The team thank staff at the Department of Environment and Science and the Department of Agriculture, Water and Environment who provided feedback on the survey.

Conflicts of Interest: The authors declare no conflict of interest. The funders had no role in the design of the study; in the collection, analyses, or interpretation of data; in the writing of the manuscript, or in the decision to publish the results.

\section{References}

1. Deloitte Access Economics. At What Price? The Economic, Social and Icon Value of the Great Barrier Reef. 2017. Available online: https:/ /www2.deloitte.com/content/dam/Deloitte/au/Documents/Economics/deloitte-au-economics-great-barrierreef-230617.pdf (accessed on 4 January 2021).

2. Waterhouse, J.; Schaffelke, B.; Bartley, R.; Eberhard, R.; Brodie, J.; Star, M.; Thorburn, P.; Rolfe, J.; Ronan, M.; Taylor, B.; et al. Land Use Impacts on Great Barrier Reef Water Quality and Ecosystem Condition. Scientific Consensus Statement 2017: A Synthesis of the Science of Land-Based Water Quality Impacts on the Great Barrier Reef; State of Queensland: Brisbane, Australia, 2017. Available online: https: //www.reefplan.qld.gov.au/_data/assets/pdf_file/0029/45992/2017-scientific-consensus-statement-summary.pdf (accessed on 4 January 2021).

3. State of Queensland. Reef 2050 Water Quality Improvement Plan 2017-2022; Queensland Government: Brisbane, Australia, 2018. Available online: https:/ /www.reefplan.qld.gov.au/_data/assets/pdf_file/0017/46115/reef-2050-water-quality-improvementplan-2017-22.pdf (accessed on 4 January 2021). 
4. State of Queensland. Prescribed Methodology for Sugarcane Cultivation; Office of the Great Barrier Reef, Environmental Policy and Programs, Department of Environment and Science, Queensland Government: Brisbane, Australia, 2019. Available online: https:/ / www.qld.gov.au/_data/assets/pdf_file/0016/113146/prescribed-method-sugarcane.pdf (accessed on 4 January 2021).

5. Calcino, D.V.; Schroeder, B.L.; Hurney, A.P. Extension and Adoption of the 'Six Easy Steps' Nutrient Management Program in Sugarcane Production in North Queensland. In Proceedings of the International Society of Sugar Cane Technologists, Veracruz, Mexico, 7-11 March 2010; Volume 27.

6. Schroeder, B.L.; Hurney, A.P.; Wood, A.W.; Moody, P.W.; Allsopp, P.G. Concepts and Value of the Nitrogen Guidelines Contained in the Australian Sugar Industry's "Six Easy Steps" Nutrient Management Program. In Proceedings of the International Society of Sugar Cane Technologists, Veracruz, Mexico, 7-11 March 2010; Volume 27, pp. 1-13.

7. Schroeder, B.L.; Wood, A.W.; Moody, P.W.; Stewart, R.L.; Panitz, J.H.; Benn, J. Soil-Specific Nutrient Management Guidelines for Sugarcane Production in the Johnstone Catchment; BSES Limited Technical Publication TE07001; BSES Limited: Indooroopilly, Australia, 2007.

8. Keating, B.A.; Verburg, K.; Huth, N.I.; Robertson, M.J. Nitrogen management in intensive agriculture: Sugarcane in Australia. In Intensive Sugarcane Production: Meeting the Challenges beyond 2000, Proceedings of the Sugar 2000 Symposium, Brisbane, Australia, 20-23 August 1996; Keating, B.A., Wilson, J.R., Eds.; CSIRO Tropical Agriculture and CRC for Sustainable Sugar Production: Brisbane, Australia, 1997; pp. 221-242.

9. Schroeder, B.L.; Wood, A.W.; Hurney, A.; Panitz, J.H. Accelerating the Adoption of Best Practice Nutrient Management: Wet Tropics; BSES Limited: Indooroopilly, Australia, 2008.

10. Chapman, L.S. Fertiliser N Management in Australia. Proc. Aust. Soc. Sugar Cane Technol. 1994, 16, 83-92.

11. Johnston, A.K.L. Risk Perceptions and Nutrient Management Responses in the Australian Sugar Industry: Preliminary Results from the Herbert River District. In Proceedings of the 17th Australian Society of Sugar Cane Technologists, Bundaberg Central, Australia, 2-5 May 1995; pp. 172-178.

12. Webster, K.; Burgess, D.; Beattie, R. Benchmark Report on North Queensland Fertiliser Use; Bureau of Sugar Experiment Stations: Brisbane, Australia, 1996.

13. Kingston, G.; Linedale, A.I. Soil Fertility and Fertiliser Application to Ratoon Cane in the Moreton Mill Area. In Proceedings of the Australian Society of Sugar Cane Technologists 9, Mackay, Australia, 27-30 April 1987; pp. 59-64.

14. Wood, A.W. Current Nitrogen Recommendations, Practices and Problems: North and Central Queensland. Integrating Research on Nitrogen Management of Sugar Cane-Report of Workshop Held 7 and 8 December 1992 as Part of the Sugar Research and Development Corporation-Funded Project CSC7S; Sugar Research and Development Corporation: Brisbane, Australia, 1992.

15. Calcino, D.V. Australian Sugarcane Nutritional Manual; SRDC/BSES: Indooroopilly, Australia, 1994.

16. Schroeder, B.L.; Webster, K.; Davies, B.; Wood, A.W.; Kingston, G. Fertiliser recommendations. In Managing Soils, Nutrients and Environment for Sustainable Sugar Production; Bruce, R.C., Ed.; CRC for Sustainable Sugar Production: Townsville, Australia, 2002; pp. 115-128.

17. Schroeder, B.L.; Salter, B.; Moody, P.W.; Skocaj, D.M.; Thorburn, P.J. Evolving nature of nitrogen management in the Australian sugar industry. In A Review of Nitrogen Use Efficiency in Sugarcane; Bell, M.J., Ed.; Report for Sugar Research Australia Limited; Sugar Research Australia Ltd.: Indooroopilly, Australia, 2014; ISBN 978-0-949678-36-2.

18. Wegener, M.A. Analysis of Risk in Irrigated Sugarcane at Mackay. In Proceedings of the Australian Society of Sugar Cane Technologists 12, Townsville, Australia, 1-4 May 1990; pp. 45-51.

19. Schroeder, B.L.; Wood, A.W.; Moody, P.W.; Panitz, J.H. Sustainable Nutrient Management-Delivering the Message to the Australian Sugar Industry. In Proceedings of the South African Sugar Technologists Association 75, Durban, South Africa, 18-20 July 2006.

20. Schroeder, B.L.; Wood, A.W.; Park, G.; Panitz, J.H.; Stewart, R.L. Validating the "SIX EASY STEPS" Nutrient Management Guidelines in the Johnstone Catchment. In Proceedings of the 2009 Conference of the Australian Society of Sugar Cane Technologists, Ballina, Australia, 5-8 May 2009; Bruce, R.C., Ed.; Australian Society of Sugar Cane Technologists: Mackay, Australia, 2009; pp. 177-185.

21. Thorburn, P.J.; Biggs, J.S.; Skocaj, D.; Schroeder, B.L.; Sexton, J.; Everingham, Y.L. Crop Size and Sugarcane Nitrogen Fertiliser Requirements: Is There a Link? Proc. Aust. Soc. Sugar Cane Technol. 2018, 40, 210-218.

22. Waters, D.K.; Carroll, C.; Ellis, R.; Hateley, L.; McCloskey, G.L.; Packett, R.; Dougall, C.; Fentie, B. Modelling Reductions of Pollutant Loads Due to Improved Management Practices in the Great Barrier Reef Catchments—Whole of GBR; Technical Report; Queensland Department of Natural Resources and Mines: Toowoomba, Australia, 2014; Volume 1, ISBN 978-1-7423-0999. Available online: https: / / www.reefplan.qld.gov.au/_data/assets / pdf_file/0027 / 46098/great-barrier-reef-catchment-modelling-report.pdf (accessed on 18 January 2021).

23. Commonwealth of Australia. Reef Trust Tender-Wet Tropics, Competitive Tender Round, Applicant Guidelines; Australian Government: Canberra, Australia, 2014.

24. Sugar Research Australia Best-Practice Nutrient Management-The Six Easy Steps Approach. 2013. Available online: https: / / sugarresearch.com.au/growers-and-millers/nutrient-management/ (accessed on 4 January 2021).

25. Commonwealth of Australia and Queensland Government. Agricultural Land Management Practice Adoption Results: Reef Water Quality Report Card 2017 and 2018, Reef 2050 Water Quality Improvement Plan. 2018. Available online: https://www. 
reefplan.qld.gov.au/_data/assets/pdf_file/0020/82901/report-card-2017-2018-results-agricultural-mpa.pdf (accessed on 4 January 2021).

26. Hay, R.; Eagle, L.; Saleem, M.A. Social Marketing's Role in Improving Water Quality on the Great Barrier Reef. Asia Pacific J. Mark. Logist. 2019. [CrossRef]

27. Rundle-Thiele, S. Measuring Cost-Effectiveness and Identifying Key Barriers and Enablers of Lasting Practice Change in the Cane Industry_Information Sheet; Reef and Rainforest Research Centre Limited: Cairns, Australia, 2018; Available online: http: //nesptropical.edu.au/wp-content/uploads/2018/09/NESP-TWQ-Project-4.12-Factsheet.pdf (accessed on 4 January 2021).

28. Preacher, K.J.; Rucker, D.D.; Hayes, A.F. Addressing Moderated Mediation Hypotheses: Theory, Methods, and Prescriptions. Multivar. Behav. Res. 2007, 42, 185-227. [CrossRef] [PubMed]

29. Farr, M.; Eagle, L.; Hay, R.; Churchill, M. Questionnaire Design, Sampling Strategy and Preliminary Findings: The Wet Tropics Region. Interim Report to the National Environmental Science Programme; Reef and Rainforest Research Centre Limited: Cairns, Australia, 2017; Available online: http:/ / nesptropical.edu.au/wp-content/uploads/2018/07/NESP-TWQ-2.1.3-INTERIM-REPORT-4.pdf (accessed on 4 January 2021).

30. Ajzen, I. The Theory of Planned Behavior. Organ. Behav. Hum. Decis. Process. 1991, 50, 179-211. [CrossRef]

31. Ajzen, I. The Theory of Planned Behaviour: Reactions and Reflections. Psychol. Health 2011, 26, 1113-1127. [CrossRef] [PubMed]

32. Zeweld, W.; Van Huylenbroeck, G.; Tesfay, G.; Speelman, S. Smallholder Farmers' Behavioural Intentions towards Sustainable Agricultural Practices. J. Environ. Manag. 2017, 187, 71-81. [CrossRef] [PubMed]

33. Truong, V.D.; Saunders, S.G.; Dong, X.D. Systems Social Marketing: A Critical Appraisal. J. Soc. Mark. 2019, 9, 180-203. [CrossRef]

34. Brychkov, D.; Domegan, C. Social Marketing and Systems Science: Past, Present and Future. J. Soc. Mark. 2017, 7, 74-93. [CrossRef]

35. Domegan, C.; McHugh, P.; Devaney, M.; Duane, S.; Hogan, M.; Broome, B.J.; Layton, R.A.; Joyce, J.; Mazzonetto, M.; Piwowarczyk, J. Systems-Thinking Social Marketing: Conceptual Extensions and Empirical Investigations. J. Mark. Manag. 2016, 32, 1123-1144. [CrossRef]

36. Van Grieken, M.E.; Webster, A.J.; Poggio, M.; Thorburn, P.J.; Biggs, J.S.; Stokes, C.; McDonald, C. Implementation Costs of Agricultural Management Practices for Water Quality Improvement in the Great Barrier Reef Catchments; CSIRO, Water for a Healthy Country National Research Flagship: Canberra, Australia, 2010.

37. Folkersen, M.V.; Fleming, C.M.; Hasan, S. Deep Sea Mining's Future Effects on Fiji's Tourism Industry: A Contingent Behaviour Study. Mar. Policy 2018, 96, 81-89. [CrossRef]

38. Kragt, M.E.; Roebeling, P.C.; Ruijs, A. Effects of Great Barrier Reef Degradation on Recreational Reef-Trip Demand: A Contingent Behaviour Approach. Aust. J. Agric. Resour. Econ. 2009, 53, 213-229. [CrossRef]

39. Cameron, A.C.; Trivedi, P.K. Microeconometrics Using STATA; STATA Press: College Station, TX, USA, 2009; ISBN 978-1-59718-048-1.

40. Hosmer, D.W.; Lemeshow, S. Applied Logistic Regression, 2nd ed.; John Wiley \& Sons, Inc.: New York, NY, USA, 2000; ISBN 0-471-35632-8.

41. Rundle-Thiele, S.; David, P.; Willmott, T.; Pang, B.; Eagle, L.; Hay, R. Social Marketing Theory Development Goals: An Agenda to Drive Change. J. Mark. Manag. 2019, 35, 160-181. [CrossRef]

42. Lemken, D.; Spiller, A.; von Meyer-Höfer, M. The Case of Legume-Cereal Crop Mixtures in Modern Agriculture and the Transtheoretical Model of Gradual Adoption. Ecol. Econ. 2017, 137, 20-28. [CrossRef]

43. Márquez-García, M.; Jacobson, S.K.; Barbosa, O. Wine with a Bouquet of Biodiversity: Assessing Agricultural Adoption of Conservation Practices in Chile. Environ. Conserv. 2019, 46, 34-42. [CrossRef]

44. Rothman, A.J. Capitalizing on Opportunities to Refine Health Behavior Theories. Health Educ. Behav. 2009, 36, 150S-155S. [CrossRef] [PubMed]

45. McHugh, P.; Domegan, C.; Duane, S. Protocols for Stakeholder Participation in Social Marketing Systems. Soc. Mar. Q. 2018, 24, 164-193. [CrossRef]

46. Blythe, J.; Sulu, R.; Harohau, D.; Weeks, R.; Schwarz, A.M.; Mills, D.; Phillips, M. Social Dynamics Shaping the Diffusion of Sustainable Aquaculture Innovations in the Solomon Islands. Sustainability 2017, 9, 126. [CrossRef]

47. Goldberger, J.R.; Jones, R.E.; Miles, C.A.; Wallace, R.W.; Inglis, D.A. Barriers and Bridges to the Adoption of Biodegradable Plastic Mulches for US Specialty Crop Production. Renew. Agric. Food Syst. 2013, 30, 143-153. [CrossRef]

48. Borremans, L.; Marchand, F.; Visser, M.; Wauters, E. Nurturing Agroforestry Systems in Flanders: Analysis from an Agricultural Innovation Systems Perspective. Agric. Syst. 2018, 162, 205-219. [CrossRef] 